\title{
Evaluation of two cooking methods and precooking treatments on characteristics of chicken breast and leg
}

\author{
By Nadia A. Salama \\ Department of Food Science and Technology, \\ University of Cairo, Faculty of Agriculture, Giza, Egypt.
}

\section{RESUMEN}

Evaluación de dos métodos de cocinado y tratamiento de precocinado sobre las características de pechuga y muslo de pollo.

Pechuga y muslo de pollo fueron tratados con soluciones de $\mathrm{NaC}$ $(4 \%)$ o STPP $(3 \%)$ antes de ser cocinados en hornos convencionales microonda. Mayor contenido en proteina, y menor contenido en grasa y oxidación lipídica (TBA) fueron encontrados en pechuga que en muslo. El tanto por ciento de humedad y los lípidos totales disminuyeron debido al proceso de cocinado. Las partes de pollo cocinadas en microonda tuvieron menos humedad e índice de TBA, mientras que las proteínas, lípidos totales, dureza de la piel y pérdida de cocinado fueron mayores que las producidas por cocinado convencional. Los asados cocinados en microonda fueron menos tiernos y ligeros en color, pero el aroma y flavor fueron mejor que los cocinados en horno convencional. El tratamiento en STPP antes del cocinado retuvo más humedad, proteína y grasa en las partes de pollo en comparación con las muestras tratadas con $\mathrm{NaCl}$ o no tratadas. Por otra parte disminuyó la pérdida de cocinado, oxidación lipídica, índice de dureza de la piel y mejoró lo tierno y el flavor.

PALABRAS-CLAVE: Cocinado - Evaluación nutricional - Método (com paración) - Pollo - Precocinado (tratamiento).

\section{SUMMARY}

Evaluation of two cooking methods and precooking treatments on characteristics of chicken breast and leg.

Breast and leg of chicken were soaked in $\mathrm{NaCl}(4 \%)$ or STPP (3\%) solutions before cooking in convention or microwave ovens. More protein, lowe fat and lipid oxidation (TBA) were found in breast than in leg. Moisture percent and total lipids decreased due to cooking process. Chicken parts cooked in microwave had less moisture and TBA values, while protein, tota lipids, shear force and cooking loss were more than that cooked conventionally. Microwave cooked roasts were less tender and lighter in colour, but aroma and flavour liked better by cooking in convention oven. Soaking in STPP before cooking retained more moisture protein and fat in chicken parts as compared with $\mathrm{NaCl}$ or untreated samples. Moreover, it decreased cooking loss, lipid oxidation, shear value and improved tenderness and flavour.

KEY-WORDS: Chicken - Cooking - Method (comparison) - Nutritional evaluation - Precooking (treatment).

\section{INTRODUCTION}

Chicken meat has a number of desirable nutritional and organoleptic properties, as well as low economic value per unit when compared to red meat. Precook marination of chicken is generally used by the fast food and convenience food industries to produce product with high consumer acceptability ratings.
The use of the microwave oven for heating meat represents a modern method of meat cookery that is extremely rapid and decreases energy costs, but it has not been well accepted by food services and homemaker for roasts due to uneven cooking, greater cooking losses and less palatable meat than conventional oven (Hutton et al., 1981). Comparing microwave and conventionally cooked meat has indicated differences in sensory, physical and chemical characteristics of the muscle tissue (Dunn and Heath, 1979, Voris and Van-Duyne, 1979, and Hutton et al., 1981).

Rancidity is detectable in some products heated by microwave but the degree of lipid deterioration is less than that caused by conventional heating method (Pikul et al., 1984, King and Bosch, 1990).

Sodium chloride $(\mathrm{NaCl})$ which added to several meat products for its functional properties was shown to promote lipid oxidation (King and Bosch, 1990). Sodium tripolyphosphate (STPP) widely used for reducing moisture losses during cooking, improved tenderness and flavour of cooked meat (Froning and Sackett, 1985, Young et al., 1987, Paterson and Parrish, 1988).

Therefore, this study was conducted to compare microwave and conventional ovens for cooking chicken meat treated with $\mathrm{NaCl}$ and STPP, with respect to some chemical, physical and sensory attributes.

\section{MATERIALS AND METHODS}

\section{Preparation of samples}

A total of 28 male Fayoumy Breed Chicken were obtained from the flack of the experimental station, Faculty of Agriculture, Cairo University. They were slaughtered at 11 weeks of age using the subscald $\left(59^{\circ}-62^{\circ} \mathrm{C}\right)$ method of feather removal. Carcasses were cut up into front and hind quarters (breast and leg parts), then kept in refrigerator for two hours until ready for treatments. Randomly, two breasts and two legs were used for chemical determinations in raw samples. 


\section{Soaking treatments}

One-third of either breast and leg chicken parts was soaked in sodium chloride $(\mathrm{NaCl})$ at $4 \%$, other third was soaked in sodium tripolyphosphate (STPP) at $3 \%$ and the later third was left without treatment (control). Soaking was carried out in jars containing solution for one hour at $25^{\circ} \mathrm{C}$.

\section{Cooking methods}

Samples of each treatment of either breast or leg parts were randomly divided into two plots, each containing 9 parts representing 3 replicates. One plot of each treatment was cooked in conventional gas oven at $177^{\circ} \mathrm{C}$ for 105 min. Other plot was cooked in microwave oven "Moulinex Electronic Type 823" for 8 min for each side of breast and $6 \mathrm{~min}$ for each side of leg.

\section{Proximate analysis}

Total moisture percent, nitrogen and ether extractable fats were determined in raw fresh samples and after cooking (in both conventional or microwave ovens) according to the procedures described in AOAC (1984).

\section{TBA assay}

Lipid oxidation in chicken parts was determined by reaction with thiobarbituric acid regent (Ohkawa et al, 1979) and TBA number were expressed in terms of milligrams of malonaldehyde per Kilogram meat.

\section{Cooking loss}

Percentage cook loss was determined by taking the weight loss after cooking and dividing it by the original raw weight after soaking treatments.

\section{Shear values evaluation}

Shear values were measured using the Warner and Bratzler apparatus (capacity $50 \times 0$. ILB). Two $2.5 \mathrm{~cm}$ cores were obtained from the cooked breast or leg meat using a portable drill corer, and shear values were made on each sample at room temperature.

\section{Sensory evaluation}

Fifteen graduate students were used to evaluate chicken parts for tenderness, flavour, and exterior colour. The samples were scored on a 10-point hedonic scale so that the panelists may rate the degree of acceptability.

\section{Statistical analysis}

The Duncan's multiple range test Steel and Torrie, 1980) was used to determine differences between the means.

\section{RESULTS AND DISCUSSION}

\section{Proximate analysis}

The means of moisture percent in chicken parts (breast and leg) decreased due to cooking process (Table I). In general, percent moisture in the microwave cooked chicken parts was less than that cooked by the conventional method. This trend has been reported previously for poultry (Proctor and Cunningham, 1983). In contrast Voris and Van-Duyne (1979) did not show significant differences in the moisture content of round beef roasts due to cooking by microwave and conventional method.

It appeared also that $\mathrm{NaCl}$ and STPP treatments retained more moisture content in treated samples during cooking than not treated ones.

STPP was more effective than $\mathrm{NaCl}$ in this respect. Similarly Young et al., (1987) found that $\mathrm{NaCl}$ and STPP increased moisture retention in poultry products, but there was an optimum level of these additives beyond which maximum moisture retention was not achieved. This probably due to the improving of meat binding properties with $\mathrm{NaCl}$ and STPP as detected by Young et al., (1987), Paterson and Parrish (1988).

Breast and leg meat that cooked by microwave retained more protein percent than that cooked conventionally (Table I). The effect of cooking method on protein percent may be due to higher losses in water soluble protein and more formation of free amino acids by conventional than microwave cooking. This finding agrees quite well with other reports on poultry (Proctor and Conningham (1983). Otherwise, the increase of protein percentage may due to the decrease in water content.

Salt $(\mathrm{NaCl})$ and sodium tripolyphosphate (STPP) treatments increased losses of total protein in chicken parts as compared with no treated samples. Higher loss was resulted by $\mathrm{NaCl}$ than by STPP regardless of the cooking methods, or chicken muscles. Similarly, Froning and Sackett (1985) recorded that $\mathrm{NaCl}$ rather than STPP increased the solubility of the myofibrillar proteins.

Total lipid level of breast muscle was low in contrast to red muscles (Table I). A result is in agreement with the finding of Pikul et al., (1984) with chicken meat Cooking methods , microwave and convention, apparently did not alter the trend of total lipids in breast and leg parts of chickens. Microwave cooking resulted in chicken meat with slightly higher lipid content than that cooked in convention oven. Similar findings were obtained by Proctor and Cunningham (1983) with poultry meat.

As for the effect of soaking in $\mathrm{NaCl}$ or STPP, it appears that either of the treatments did not show appreciable effect on total lipids contents of chicken parts. These results coincide with that found by Babji et al., (1982) with turkey breast muscle.

\section{TBA Assay}

Lipid oxidation causes deterioration of meat quality, especially during heating and subsequent storage (Melton, 
Table I

Average chemical analysis TBA, cooking losses and shear values of treated and untreated poultry breast and leg after cooking by two different methods.

\begin{tabular}{|c|c|c|c|c|c|c|}
\hline \multirow[t]{2}{*}{ CHICKEN SAMPLES } & \multicolumn{3}{|c|}{$\begin{array}{l}\text { Chemical composition on } \\
\text { wet weight basis }\end{array}$} & \multirow{2}{*}{$\begin{array}{c}\text { TBA mg } \\
\text { malonaldehyde/ } \\
\text { Kg meat }\end{array}$} & \multirow[t]{2}{*}{$\begin{array}{l}\text { Cooking } \\
\text { loss } \%\end{array}$} & \multirow[t]{2}{*}{$\begin{array}{l}\text { Shear } \\
\text { values }\end{array}$} \\
\hline & Moisture \% & Protein \% & Fat $\%$ & & & \\
\hline & \multicolumn{6}{|c|}{ Cooking in conventional oven } \\
\hline Breast soaked in & & & & & & \\
\hline $4 \% \mathrm{NaCl}$ & $65.35^{\mathrm{de}}$ & $24.65^{\mathrm{e}}$ & $4.56^{\text {efg }}$ & $2.614^{b}$ & $26.21^{\mathrm{d}}$ & $6.50^{\text {def }}$ \\
\hline $3 \%$ STPP & $65.85^{\mathrm{cd}}$ & $24.88^{\mathrm{e}}$ & $5.04^{\mathrm{de}}$ & $0.764^{1}$ & $25.46^{\mathrm{d}}$ & $7.70^{b c}$ \\
\hline Control & $63.78^{\text {gh }}$ & $26.42^{b}$ & $4.37^{9}$ & $1.826^{\mathrm{cd}}$ & $37.60^{b}$ & $8.20^{b}$ \\
\hline \multicolumn{7}{|l|}{ Leg soaked in } \\
\hline $4 \% \mathrm{NaCl}$ & $67.32^{\mathrm{ab}}$ & $18.05^{1}$ & $8.54^{\mathrm{bc}}$ & $2.967^{\mathrm{a}}$ & $30.95^{\mathrm{c}}$ & $5.9^{e f}$ \\
\hline 3\%STPP & $67.85^{\mathrm{a}}$ & $18.50^{i}$ & $8.81^{a b}$ & $0.840^{1}$ & $26.26^{d}$ & $5.50^{f}$ \\
\hline \multirow[t]{2}{*}{ Control } & $63.93^{\mathrm{fg}}$ & $21.68^{9}$ & $8.35^{b c}$ & $2.060^{c}$ & $38.20^{b}$ & $6.7^{\mathrm{cde}}$ \\
\hline & \multicolumn{6}{|c|}{ Cooking in microwave oven } \\
\hline \multicolumn{7}{|l|}{ Breast soaked in } \\
\hline $4 \% \mathrm{NaCl}$ & $64.47^{\mathrm{fg}}$ & $25.19^{d}$ & $4.96^{\mathrm{det}}$ & $1.667^{d}$ & $26.47^{\mathrm{d}}$ & $7.60^{\text {bcd }}$ \\
\hline $3 \%$ STPP & $64.77^{e t}$ & $25.64^{\mathrm{c}}$ & $5.40^{\mathrm{d}}$ & $0.507^{g}$ & $25.71^{d}$ & $8.60^{\mathrm{ab}}$ \\
\hline Control & $62.05^{h}$ & $27.99^{\mathrm{a}}$ & $8.35^{t}$ & $0.805^{f}$ & $38.70^{\mathrm{a}}$ & $9.37^{\mathrm{a}}$ \\
\hline \multicolumn{7}{|l|}{ Leg soaked in } \\
\hline $4 \% \mathrm{NaCl}$ & $66.50^{b c}$ & $19.41^{h}$ & $8.76^{a b c}$ & $2.559^{b}$ & $31.53^{c}$ & $6.60^{\text {cdet }}$ \\
\hline $3 \%$ STPP & $67.00^{b}$ & $19.55^{h}$ & $9.05^{\mathrm{a}}$ & $0.688^{19}$ & $26.53^{d}$ & $6.05^{e f}$ \\
\hline Control & $63.12^{h}$ & $22.16^{1}$ & $8.61^{a b c}$ & $1.399^{\mathrm{e}}$ & $39.50^{a}$ & $7.97^{b}$ \\
\hline \multicolumn{7}{|l|}{${ }^{\star}$ Raw samples } \\
\hline Breast & 76.34 & 12.39 & 6.01 & 0.822 & - & - \\
\hline Leg & 75.30 & 8.82 & 11.22 & 1.597 & - & - \\
\hline
\end{tabular}

Means in the same column with different letters are significantly different at the 0.5 level.

${ }^{\star}$ Not included in statistical analysis.

1983). The TBA assay measures the release of malonaldehyde, a secondary oxidation product of polyunsaturated fatty acids (Pearson et al., 1983), and is said to be highly correlated with warmed-over flavour in muscle foods.

In general, the TBA values of chicken leg meat was higher than that of breast meat (Table I). This finding is in agreement with that found by Pitkul et al., (1984) on lipid oxidation in chicken meat, since leg meat muscle had much more total lipids and two-fold more fat than breast meat. They added that phospholipid fraction contributed approximately $90 \%$ of the malonaldehyde measured in fat of chicken meat.

Lipid oxidation of microwave cooked samples appeared to be less than that of the conventionally heated samples. Similar results were obtained by Pikul et al., (1984), King and Bosch (1990) on chicken and turkey meat. It could be attributed to inhibition of oxidation by Millard reaction products produced during heating by microwave (Angelo and Bailey, 1987).

Soaking of chicken meat in $\mathrm{NaCl}$ before cooking accelerated oxidative rancidity as compared with untreated control samples. Similarly, King and Earl (1988) King and Bosch (1990) also showed that $\mathrm{NaCl}$ promoted lipid oxidation in poultry and turkey meats. The effect of $\mathrm{NaCl}$ was suggested to be due to metal impurities especially iron or copper (King and Bosch, 1990). On the other side, sodium tripolyphosphate treatment resulted in lower TBA values than either control or $\mathrm{NaCl}$ treatment. Paterson and Parrish
(1988) on beef roosts further found the prooxidant effect of salt have been marked by the antioxidant properly of the phosphates.

\section{Cooking loss}

Results shown in Table I reveal the influence of cooking method and soaking solutions on total cooking losses of chicken parts. Without the soaking treatments (control) the data indicated a tendency for cooking loss to be greater with microwave than with conventional cooking. This finding is in agreement with that found by Pikul et al., (1984) in chicken meat. Voris and Van Duyne (1979) also recorded a significantly higher mean drip loss with microwave cooking than did conventional roasting. Hall and Lin (1981) added that broiler chickens cooked in the microwave oven had visible evidence of dehydration around the edges.

The difference in losses between the two cooking methods was much less for breast than for leg $(2.9 \%$ and $3.4 \%$ for untreated breast and leg parts respectively). Such difference may be due to high losses of volatile fraction and drip from leg than from breast as previously recorded by Culotta and Chen (1973). High fat content in leg than in breast parts as indicated in table I could ascertain this explanation.

Soaking of chicken part (breast and leg) in $\mathrm{NaCl}$ or STPP solution before cooking reduced pronouncedly percentage of cooking losses during cooking either in con- 
vention or microwave oven when compared with untreated parts. Regardless of the cooking method sodium tripolyphosphate treatment was more effective in decreasing cooking losses than sodium chloride. In addition, leg muscles responded further to STPP treatment than breast muscles. Similarly, Froning and Sackett (1985), Young et al. (1987) and Paterson and Parrish (1988) revealed that both $\mathrm{NaCl}$ and STPP reduced cooking losses in turkey, chicken and beef meats respectively, through improving their binding properties. Babji et al., (1982) explained the binding effect of salt by increasing the solubility of the myofibrillar proteins.

\section{Shear values}

Mean Warner-Bratzler shear values indicated that microwave cooked breast and leg muscles required greater amount of force to shear the samples than that cooked in conventional oven (Table I). Similar finding was obtained by Voris and Van-Duyne (1979) with top round roasts, which may be due to higher mean drip loss with microwave than conventional cooking. Otherwise, Roberts and Lawrie (1974) suggested that use of microwave oven does not allow time for collagen solubilization and tenderization.

Leg muscles required less force to compress than breast muscles. Also, treatment of both chicken muscles with $\mathrm{NaCl}$ or STPP before cooking resulted in less shear values as compared with untreated samples. This finding may be due to the increased moisture content in samples had low shear values (Table I). Similar, Paterson and Parrish (1988) indicated that the improving effect of $\mathrm{NaCl}$ and STPP on shear force to be due to their effect on increasing water binding properties of meat samples.

\section{Sensory evaluation}

Average score values of sensory attributes aroma tenderness, flavour, and exterior colour are shown in table II . In general the objective tenderness evaluation by taste panel agrees with the subjective shear press values of the same samples. This is true for both microwave and conventionally cooked breast and leg chicken meat received different treatments under investigation. This finding goes in parallel with the results of Dunn and Heath (1979) on poultry meat. It appeared also that dark meat received the best scores for tenderness in comparison to white meat, that agree with that findings by of Culotta and Chen (1973) on chicken. Microwave cooked chicken parts were less tender, but not significant, than that cooked in a conventional oven. Similar findings were obtained by Dunn and Heath (1979) on poultry. This may be due to degradation of the collagenous connective tissue and/or increased proteolytic enzyme activity that induced change in myofibrillar proteins with slow heat in convention oven than fast heat in microwave oven as cited by Hutton et al., (1981). Sodium tripolyphosphate has been found to improve tenderness and followed by sodium chloride as compared with control. This result is in agreement with the finding of Froning and Sackett (1985), Young et al., (1987), Paterson and Parrish (1988) as STPP especially when combined with $\mathrm{NaCl}$ improved tenderness of turkey, chicken and beef meats respectively. Aroma and flavour of the samples cooked by conventional oven was predicted to be liked better than that cooked by microwave. Similar results were obtained by Voris and Van Duyne (1979) on beef meat while Dunn and Heath (1979) did not show significant differences in flavour may be attributed to the differences in aroma of volatile components with the longer cooking time by conventional heating than microwave method (MacLeod and Coppock, 1976). Soaking of breast and leg muscles in sodium chloride of sodium tripolyphosphate improved the flavour as compared with control. Similar findings were obtained by Froning and Sackett (1985) with turkey breast muscle color of microwave cooked roasts was significantly lighter than the conventional roasts. The lower flavour scores of microwave roasts may be related to this lack of browning, since browning reactions are important in the development of flavour as well as colour (Voris and Van Duyne, 1979).

Table II

\section{Sensory evaluation scores of treated and untreated poultry breast and leg after cooking by} two different methods

\begin{tabular}{|c|c|c|c|c|}
\hline \multirow{2}{*}{$\begin{array}{l}\text { CHICKEN } \\
\text { SAMPLES }\end{array}$} & \multicolumn{3}{|c|}{ Palatability factors } & \multirow{2}{*}{$\begin{array}{c}\text { Exterior } \\
\text { colour }\end{array}$} \\
\hline & Aroma & Tenderness & Flavour & \\
\hline & \multicolumn{4}{|c|}{ After cooking in conventional oven } \\
\hline \multicolumn{5}{|c|}{ Breast soaked in } \\
\hline $4 \% \mathrm{NaCl}$ & $7.4^{\mathrm{ab}}$ & $7.8^{\mathrm{cd}}$ & $7.4^{\mathrm{ab}}$ & $7.3^{\mathrm{a}}$ \\
\hline $3 \%$ STPP & $7.5^{\mathrm{a}}$ & $8.2^{\mathrm{abc}}$ & $7.8^{\mathrm{a}}$ & $7.4^{\mathrm{a}}$ \\
\hline Control & $7.1^{\mathrm{abc}}$ & $7.1^{\mathrm{e}}$ & $6.8^{\text {cde }}$ & $7.2^{\mathrm{a}}$ \\
\hline \multicolumn{5}{|c|}{ Leg soaked in } \\
\hline $4 \% \mathrm{NaCl}$ & $7.5^{\mathrm{a}}$ & $8.2^{\mathrm{abc}}$ & $6.8^{\text {cde }}$ & $7.2^{\mathrm{a}}$ \\
\hline 3\%STPP & $7.4^{\mathrm{ab}}$ & $8.7^{\mathrm{a}}$ & $6.9^{\text {cd }}$ & $7.3^{\mathrm{a}}$ \\
\hline \multirow[t]{2}{*}{ Control } & $7.0^{\mathrm{bcd}}$ & $7.8^{\mathrm{cd}}$ & $6.4^{\mathrm{defg}}$ & $7.1^{\mathrm{a}}$ \\
\hline & \multicolumn{4}{|c|}{ After cooking in microwave oven } \\
\hline \multicolumn{5}{|c|}{ Breast soaked in } \\
\hline $4 \% \mathrm{NaCl}$ & $7.0^{\mathrm{bcd}}$ & $7.6^{\text {cde }}$ & $6.7^{\text {def }}$ & $6.1^{\mathrm{b}}$ \\
\hline $3 \%$ STPP & $7.1^{\mathrm{abc}}$ & $7.9^{\mathrm{bcd}}$ & $7.2^{\mathrm{bc}}$ & $6.0^{\mathrm{b}}$ \\
\hline Control & $6.9^{\mathrm{cd}}$ & $7.3^{\theta}$ & $6.2^{\mathrm{fg}}$ & $6.1^{b}$ \\
\hline \multicolumn{5}{|c|}{ Leg soaked in } \\
\hline $4 \% \mathrm{NaCl}$ & $6.7^{\text {cd }}$ & $8.0^{\mathrm{bcd}}$ & $6.2^{f g}$ & $6.0^{\mathrm{b}}$ \\
\hline $3 \%$ STPP & $6.8^{\text {cd }}$ & $8.5^{\mathrm{ab}}$ & $6.5^{\text {defg }}$ & $6.1^{\mathrm{b}}$ \\
\hline Control & $6.6^{d}$ & $7.4^{\mathrm{de}}$ & $6.0^{9}$ & $6.2^{\mathrm{b}}$ \\
\hline
\end{tabular}

Means in the same column with different letters are significantly different at the 0.5 level.

\section{REFERENCES}

Angelo, A. J. and Bailey, M. E. Warmed (1987).- "Over flavour of meat".- Academic Press, Orlando, U.S.A.

AOAC (1984).- "Official Method of Analysis".- 13th ed.- Association of Official Analytical Chemists, Washington, D.C.

Babji, A. S., Froning, G. W. and Ngoka, D. A. (1982).- "The effect of short-term tumbling and salting on the quality of turkey breast muscle".J. Poultry Sci. 61, 300 .

Baldwin, R. E., Korschgen, B. M. and Krause, G. F. (1979)."Comparison of sensitivity of microwave and conventional methods for meat cookery".- J. Food Sci. 44, 624. 
Culotta, J. T. and Chen, T. C. (1973).- "Hot water and microwave energy for precooking chicken parts: Effects on yield and organoleptic quality".-- J. Food Sci. 38, 860

Dunn, N. A. and Heath, J. L. (1979).- "Effect of microwave energy on poultry tenderness".- J. Food Sci. 44, 339.

Froning, G.W. and Sackett, B. (1985).- "Effect of salt and phosphates during tumbling of turkey breast muscle on meat characteristics".- J. Poultry Sci. 64,1328

Hall, K. N. and Lin, C. S. (1981).- "Effect of cooking rates in electric or microwave oven on cooking losses and retention of thiamin in broilers".- J. Food Sci. 46, 1292.

Hutton, C. W., Neggers, Y. H. and Love, T. O. (1981).- "Scanning electron microscopy, proteolytic enzyme activity, and acceptability of beef semitendinosus cooked by microwaves and conventional heat".- J. Food Sci. 46, 1309.

King, A. J. and Bosch, N. (1990).- "Effect of $\mathrm{NaCl}$ and $\mathrm{KCl}$ on rancidity of dark turkey meat heated by microwave".- J. Food Sci. 55, 1549.

Macleod, G. and Coppock, B. M. (1976).- "Volatile flavor components of beef conventionally and by microwave radiation".- J. Agric. Food Chem. 24, 835.

Melton, S. L. (1983).- "Methodology for following lipid oxidation in muscle foods".- Food Technol. 37, 105.

Ohkawa, H., Ohishi, N. and Yagi, K. (1979).- "Assay for lipid peroxides in animal tissues by thiobarbituric acid reaction".- Anal. Biochem. 95, 351.

Paterson, B. C. and Parrish, F. C. (1988).- "Factors affecting the palatability and shelf life of precooked, Microwave - Reheated beef Roasts".- J. Food Sci. 53, 37

Pearson, A. M., Gray, J. I., Wolzak, A. M. and Horenstein, N. A. (1983).- "Safety implications of oxidized lipids in muscle foods".- Food Technol. 37, 121.

Pikul, J., Leszczynski, D. E. and Kummerow, F. A. (1984).- "Relative role of phospholipids triacylglycerols, and cholesterol esters on malonaldehyde formation in fat extracted from chicken meat".- J. Food Sci. 49, 704.

Pikul, J., Leszczynski, D. E., Bechtel, P. J. and Kummerow, F. A. (1984).- "Effects of frozen storage and cooking on lipid oxidation in chicken meat".- J. Food Sci. 49, 838.

Proctor, V. A. and Cunningham, F. E. (1983).- "Composition of broiler meat as influenced by cooking methods and coating" - J. Food Sci. 48, 1696.

Roberts, P. C. B. and Lawrie, R. A. (1974).- "Effects of bovine dorsi muscle of conventional and microwave heating".- J. Food Technol. 9, 345.

Stell, R. G. D. and Torrie, J. H. (1980).- "Principles and Procedures of Statistics".- 2nd ed.- McGraw - Hill, New York.

Voris, H. H. and Von-Duyne, F. O. (1979).- "Low wattage microwave cooking of top round Roasts: Energy consumption thiamine content and palatability".- J. Food Sci. 44, 1447.

Young, L. L., Lyon, C. E. Searcy, G. K. and Wilson, R. L. (1987)."Influence of sodium tripolyphosphate and sodium chloride on moisture-retention and textural characteristics of chicken breast meat patties".- J. Food Sci. $52,571$.

(Recibido: Julio 1992) 